\title{
SEBARAN DAERAH TANGKAP IKAN TONGKOL (Euthynnus sp.) DI PERAIRAN SELATAN JAWA
}

\section{DISTRIBUTION AREA OF FISHING MACKEREL (Euthynnus sp.) IN THE COASTAL OF SOUTHERN JAVA}

\author{
Ibrahim Kholilullah ${ }^{1}$, Roza Yusfiandayani ${ }^{2}$, Alan F Koropitan ${ }^{1}$ \\ ${ }^{1}$ Departemen Ilmu dan Teknologi Kelautan, \\ ${ }^{2}$ Departemen Pemanfaatan Sumberdaya Perikanan, \\ Fakultas Perikanan dan Ilmu Kelautan, Institut Pertanian Bogor \\ Korespondensi: kholilullahibrahim@gmail.com
}

\begin{abstract}
The high utilization of the community towards mackerel is contradicted by the majority of the fleet owned by fishermen in South Java in the form of gill net and long line which are the specifications for capturing other large tuna and pelagic. Maps of mackerel fishing areas are needed by fishermen, especially when the fish famine season takes place as the backbone of the fishermen's catch. Raw data of the catch is obtained from the log book of Cilacap Oceanic Fishing Port catch throughout 2017. This research aimed to (1) analyze the distribution of mackerel fishing for gill net and long line fishing gear in the coastal of South Java and (2) analyze the distribution of the average layer thickness of the optimum water temperature and salinity for mackerel. The result of this study shows that the number of mackerel fishing areas (Euthynnus sp.) for gill net fishing equipment is $105,56^{\circ}-110,78^{\circ} \mathrm{E}$ and $7,48^{0}-11,57^{\circ} \mathrm{S}$ and for long line fishing gear is $106,69^{\circ}-109,46^{\circ} \mathrm{E}$ and $7,84^{\circ}-9,37^{\circ} \mathrm{S}$. The distribution of mackerel fishing areas using the highest gill net in August with the acquisition of $76.634 \mathrm{~kg}$ of catch, while using the long line in July with the acquisition of catch results of $18.741 \mathrm{~kg}$. The upright distribution of the average water temperature for mackerel is optimal in July, August, September for gill net and July and November for the long line, $26-27^{\circ} \mathrm{C}$. The upright distribution of monthly average water salinity for mackerel is also optimum in July, August, September for gill net and long line throughout the year except January is the optimum range which ranges from 34,0 to $43,3 \%$.
\end{abstract}

Keyword: distribution, fishing gear, mackerel, South Java

\begin{abstract}
ABSTRAK
Tingginya pemanfaatan masyarakat terhadap ikan tongkol kontradiksi dengan mayoritas armada kapal yang dimiliki nelayan di Selatan Jawa berupa gill net dan long line yang spesifikasi untuk menangkap tuna dan pelagis besar lainya. Peta daerah penangkapan ikan tongkol sangat dibutuhkan oleh nelayan, terutama ketika musim paceklik ikan berlangsung menjadi tulang punggung hasil tangkap nelayan. Raw data penangkapan diperoleh dari logbook penangkapan Pelabuhan Perikanan Samudera Cilacap (PPS Cilacap) sepanjang tahun 2017. Penelitian ini bertujuan (1) menganalisis sebaran daerah penangkapan ikan tongkol (Euthynnus sp.) untuk alat tangkap gill net dan long line di perairan selatan Jawa dan (2) menganalisis sebaran menegak lapisan rata-rata bulanan suhu dan salinitas perairan yang optimum untuk ikan tongkol. Hasil penelitian ini menunjukkan sebaran daerah penangkapan ikan tongkol (Eutbynnus sp.) untuk alat tangkap gill net adalah $105,56^{\circ}-110,78^{\circ} \mathrm{BT}$ dan $7,48^{\circ}-11,57^{\circ}$ LS serta untuk alat tangkap long line adalah $106,69^{\circ}-109,46^{\circ} \mathrm{BT}$ dan $7,84^{\circ}-9,37^{\circ}$ LS. Sebaran daerah penangkapan ikan tongkol menggunakan gill net tertinggi pada bulan Agustus dengan perolehan hasil tangkap $76.634 \mathrm{~kg}$, sedangkan menggunakan long line pada bulan Juli dengan perolehan hasil tangkap $18.741 \mathrm{~kg}$. Sebaran menegak lapisan rata-rata bulanan suhu perairan untuk ikan tongkol optimum pada bulan Juli, Agustus, September untuk gill net dan bulan Juli serta November untuk long line yaitu $26-27^{\circ} \mathrm{C}$. Sebaran menegak ratarata bulanan salinitas perairan untuk ikan tongkol juga optimum bulan Juli, Agustus, September untuk gill net dan long line sepanjang tahun kecuali bulan Januari merupakan kisaran optimum yaitu berkisar 34,0-43,3 \%o.
\end{abstract}

Kata kunci: alat tangkap, sebaran, Selatan Jawa, tongkol 


\section{PENDAHULUAN}

Hasil tangkap di suatu wilayah perairan berfluktuasi terhadap musim (Wiyono 2010). Besar kecilnya perolehan hasil tangkapan dipengaruhi beberapa faktor, diantaranya penentuan fishing ground (Mujib et al. 2013), jenis alat tangkap, ukuran kapal, dan cara pengoperasian alat tangkap (Hakim et al. 2018). Pemilihan alat tangkap mengacu pada tingkah laku jenis ikan dan habitat dimana ikan berada. Perairan Selatan Jawa yang memiliki industri penangkapan dari skala masyarakat sampai besar (Mertha et al. 2006), merupakan perairan laut dalam Samudera Hindia. Berbagai jenis ikan tuna dan pelagis besar lainya menjadi komoditi primadona hasil tangkap, sehingga nelayan di perairan Selatan Jawa banyak menggunakan alat tangkap gill net dan long line.

Gill net disebut juga jaring insang karena cara tangkapnya di bagian insang pada mata jaring karena menabrak jaring. Bagian utamanya berupa selembar jaring yang dilengkapi dengan tali ris atas dan bawah. Ukuran mata jaring disesuaikan dengan ukuran ikan yang menjadi target tangkapan utama. Tali ris atas ditambahkan tali berpelampung dan pada tali ris bawah dilengkapi tali berpemberat (Puspito 2009). Berapa gillnet/jaring insang serta gambarnya yang sering digunakan di Indonesia antara lain: jaring liong bun (Gambar 1), jaring gill net oseanik (Gambar 2), jaring insang lingkar (encircling gillnets) (Gambar 3), jaring insang berpancang (fixed gillnets) (Gambar 4), jaring klitik (Gambar 5), jaring insang kombinasi dengan trammel net (Gambar 6) (KKP 2017).

Long line dalam bahasa lokal disebut rawai, alat tangkap ini merupakan alat tangkap yang sederhana yang terbuat dari pancing yang ditambatkan (diikatkan) pada seutas tali yang panjang dan mata pancing (Syofyan et al. 2015). Long line digolongkan menjadi dua yaitu long line dasar (set longlines) (Gambar 7) dan long line hanyut (drifting longlines). Long line hanyut yang sering digunakan di Indonesia adalah long line tuna (Gambar 8) dan long line cucut/hiu (Gambar 9) (KKP 2017).

Rusmilyansari (2012) mengatakan gill net dan long line memiliki selektifitas tinggi. Gill net merupakan jenis alat perikanan tuna rakyat di Samudera Hindia, biasa digunakan di Pelabuhanratu. Long line digunakan untuk menangkap tuna-tuna besar yang ada pada kedalaman 100-300 m, sering digunakan nelayan dari Cilacap (Mertha et al. 2006). Gill net nelayang di Cilacap memiliki panjang 38-40 m, tinggi 18-20 $\mathrm{m}$ dan tali pelampung $6 \mathrm{~m}$, sehingga penggunaanya terdapat di lapisan permukaan (Widodo et al. 2011).

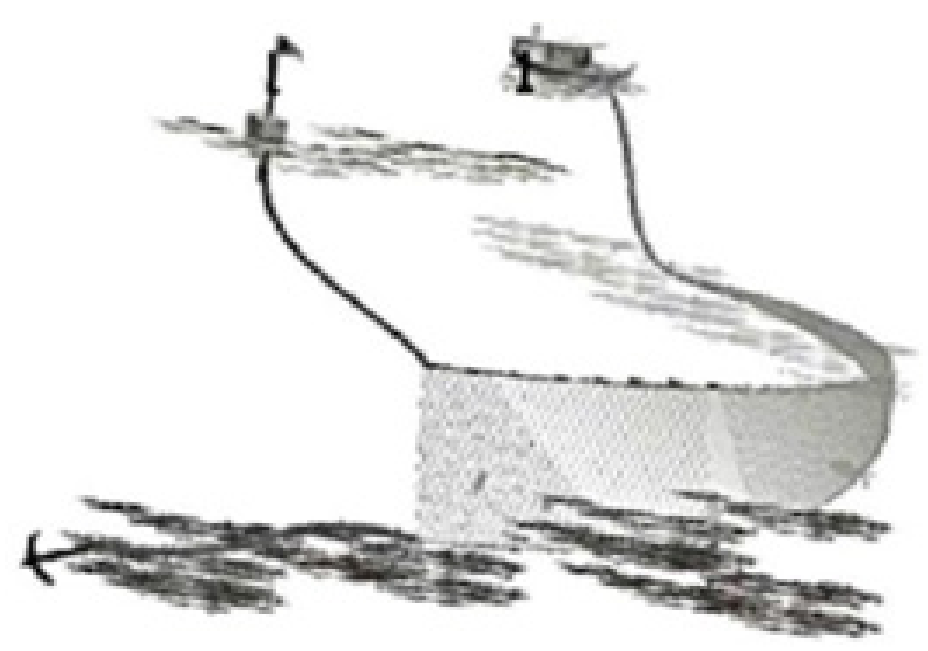

Gambar 1. Jaring liong bun 


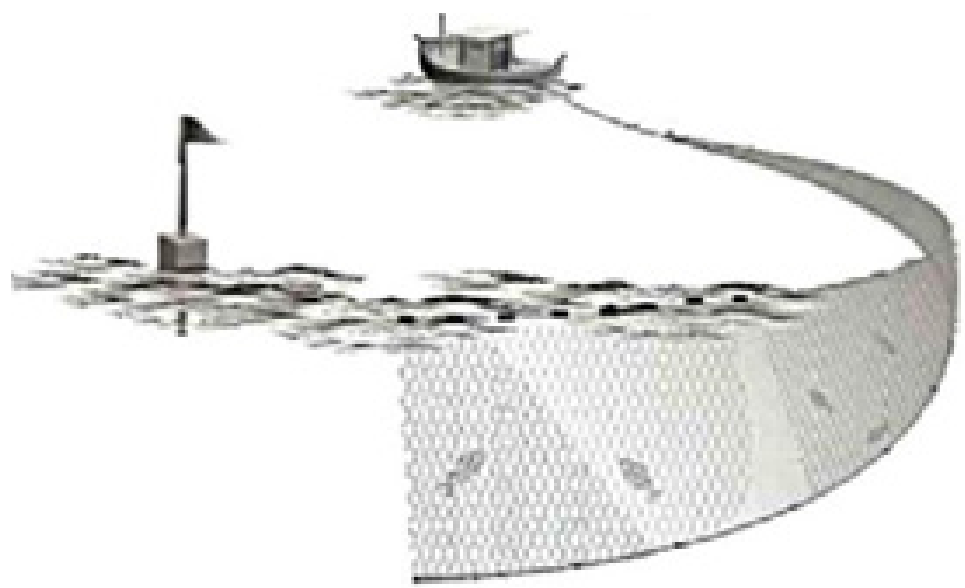

Gambar 2. Jaring gill net oseanik

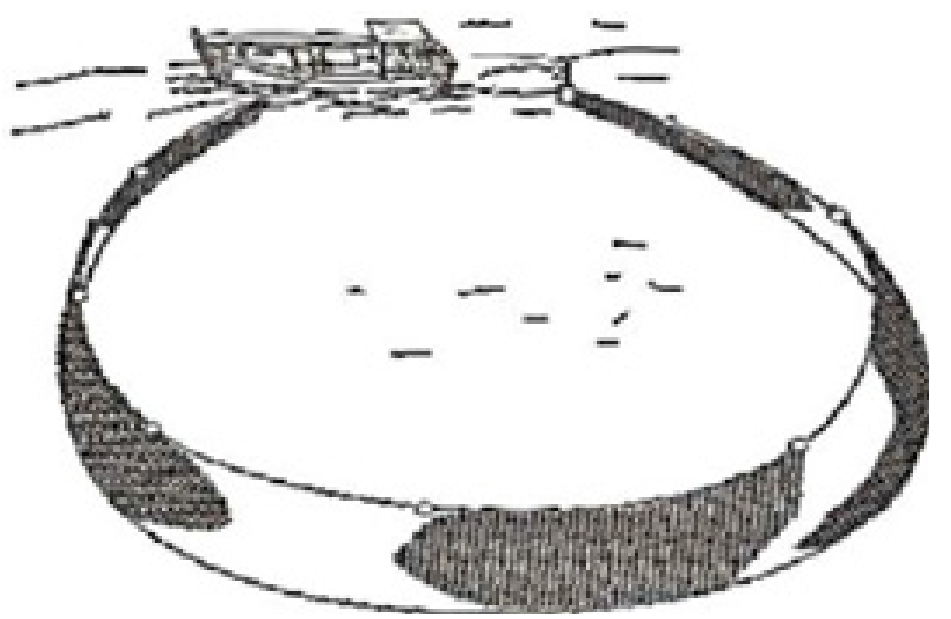

Gambar 3. Jaring insang lingkar (encircling gillnets)

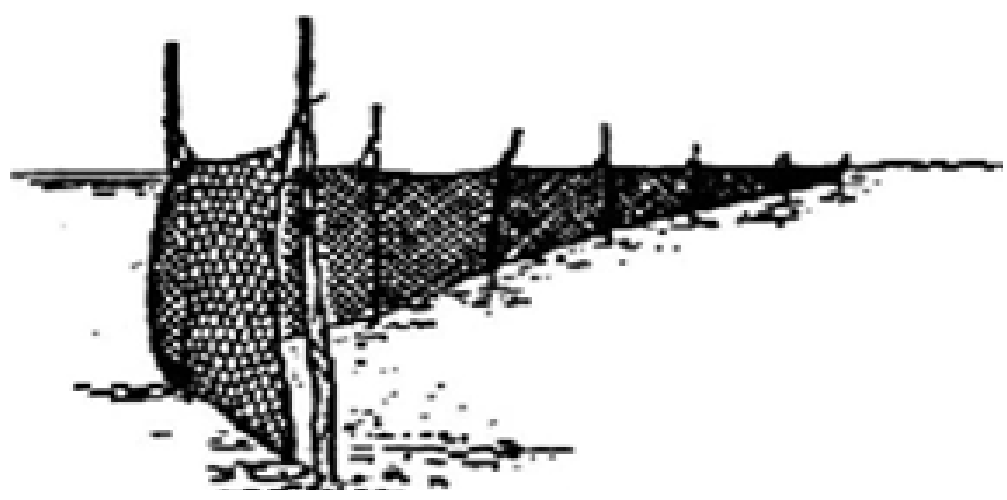

Gambar 4. Jaring insang berpancang (fixed gillnets) 


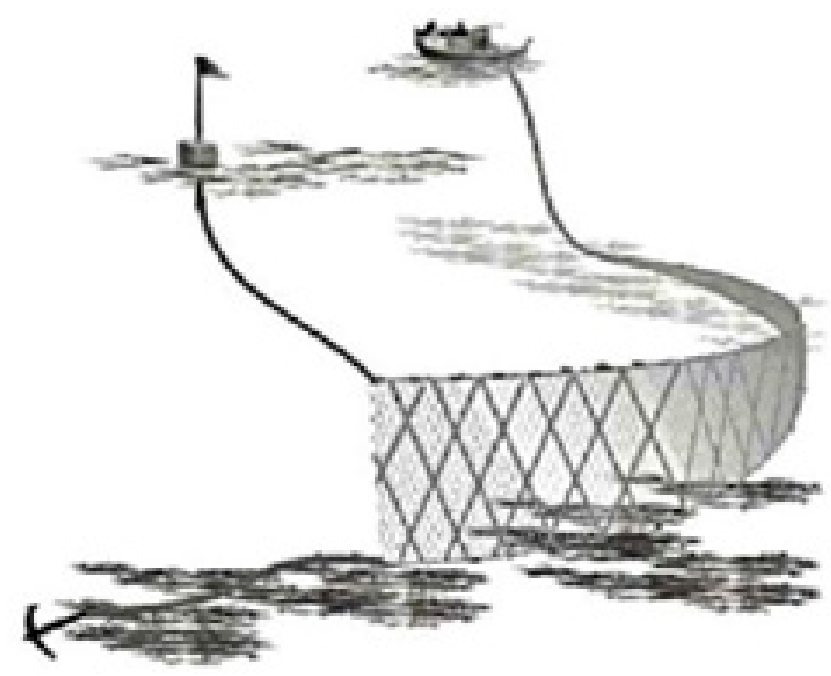

Gambar 5. Jaring klitik

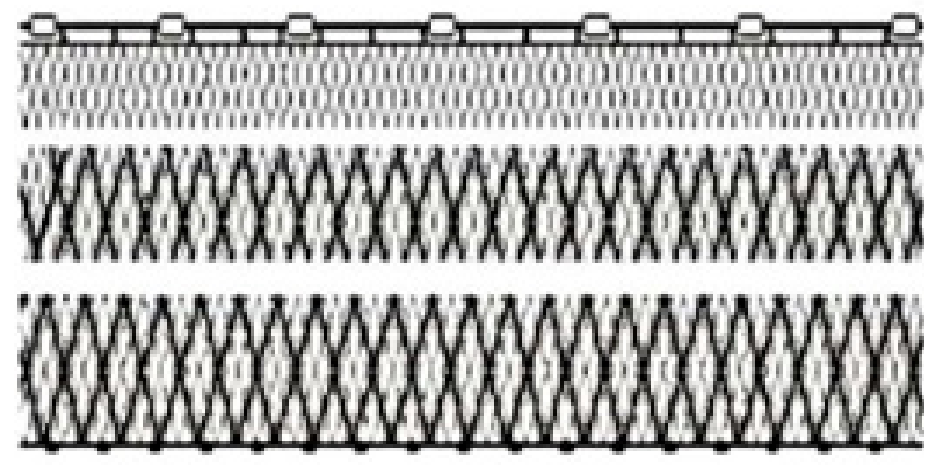

Gambar 6. Jaring insang kombinasi dengan trammel net

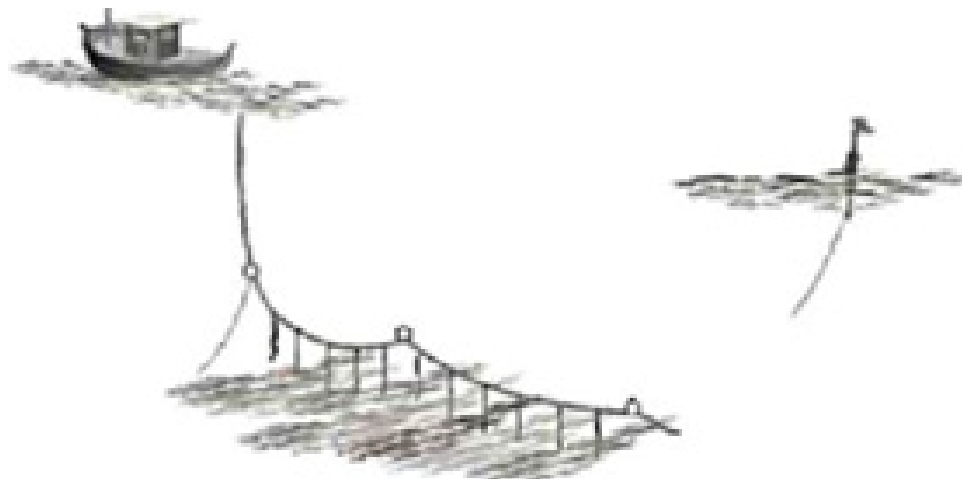

Gambar 7. Long line dasar 


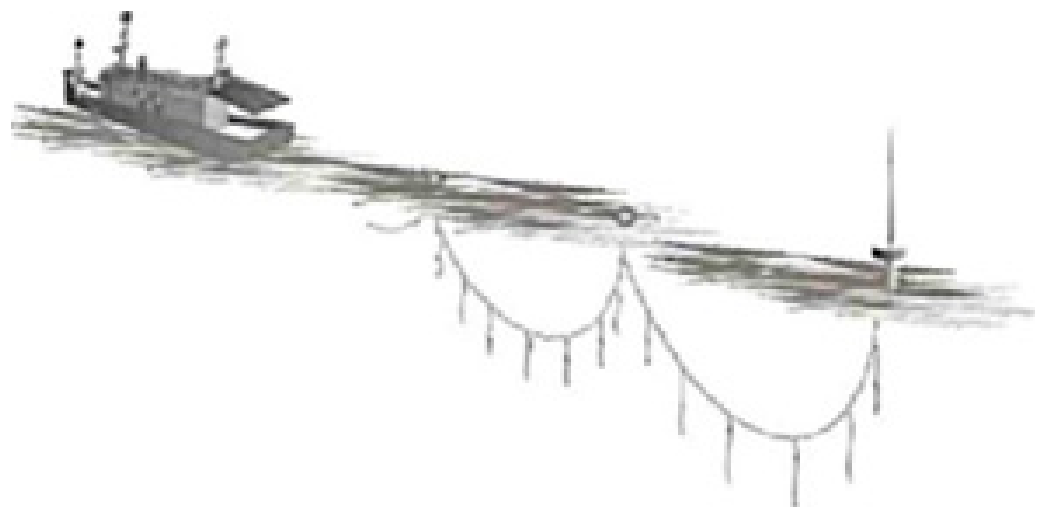

Gambar 8. Long line tuna
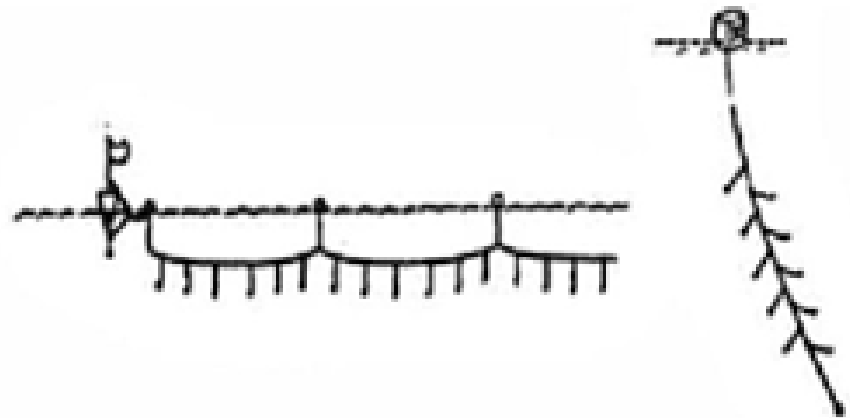

Gambar 9. Long line cucut

Perbedaan swimming layer ikan yang membedakan target tangkap dari kedua alat ini. Beberapa swimming layer ikan tuna yang komersial diantaranya yellowfin tuna dan Thunnus albacares pada kedalaman 80-170 $\mathrm{m}$ (Barata et al. 2011), big eye tuna berkisar 300-400 m (Nugraha \& Triharyuni 2009). Sementara swimming layer ikan tongkol berada pada 0-200 $\mathrm{m}$ dengan suhu berkisar $18-29^{\circ} \mathrm{C}$ (FAO-FIGIS 2005). Adyas et al. (2011) memberikan ilustrasi kaitan ikan yang tertangkap pada long line dengan ratarata kedalaman long line (Gambar 10). Pada penangkapan pelagis kecil penelitian oleh Hakim \& Nurhasanah (2017) menjelaskan, gill net berukuran 29, 30, dan 33 GT memiliki selektifitas yang tinggi sekaligus efektif dalam mendapatkan pelagis kecil yaitu ikan tenggiri dan tongkol. Tuna long line ikan tongkol dan pelagis kecil lainya terkadang bukan merupakan hasil tangkap utama (sampingan) (Adyas et al. 2011).

Ikan-ikan tuna dan pelagis besar di perairan Selatan Jawa tergolong musiman, hanya ada setiap puncak musim Timur. Lain halnya dengan pelagis kecil yang keberadaannya sepanjang tahun.
Meskipun kelimpahannya juga mengikuti musiman, tetapi keberadaanya menjadi tulang punggung hasil tangkap nelayan. Permintaan pasar untuk pelagis kecil selalu meningkat, konsumsi sehari-hari, pasar ekspor, umpan perikanan tuna menjadi penyebabnya (Ilhamdi et al. 2016). Hal ini tercermin dalam laporan Departemen Koperasi dan UMKM 2007 menyatakan pemanfaatan sumber daya ikan laut daerah Samudera Hindia untuk ikan tongkol 58\% dan tuna hanya 38\% (Talib 2017). Tingginya pemanfaatan masyarakat terhadap ikan tongkol kontradiksi dengan mayoritas armada kapal yang dimiliki nelayan di Selatan Jawa berupa Gill Net (GN) dan Long Line (LL) yang spesifikasi untuk menangkap tuna dan pelagis besar lainya. Peta daerah penangkapan ikan tongkol sangat dibutuhkan oleh nelayan, terutama ketikan musim paceklik ikan berlangsung.

Penelitian hasil tangkap di perairan Selatan Jawa sudah banyak di lakukan (Saputra et al. 2011; Kisworo et al. 2013; Nurhayati 2013; Prayitno et al. 2017). Tetapi objek penelitian-penelitian tersebut didominasi oleh pelagis besar. Maka tujuan 
penelitian ini adalah (1) menentukan sebaran daerah penangkapan ikan tongkol (Euthynnus sp.) untuk alat tangkap gill net dan long line di perairan selatan Jawa dan
(2) menganalisis sebaran menegak lapisan rata-rata bulanan suhu dan salinitas perairan yang optimum untuk ikan tongkol.

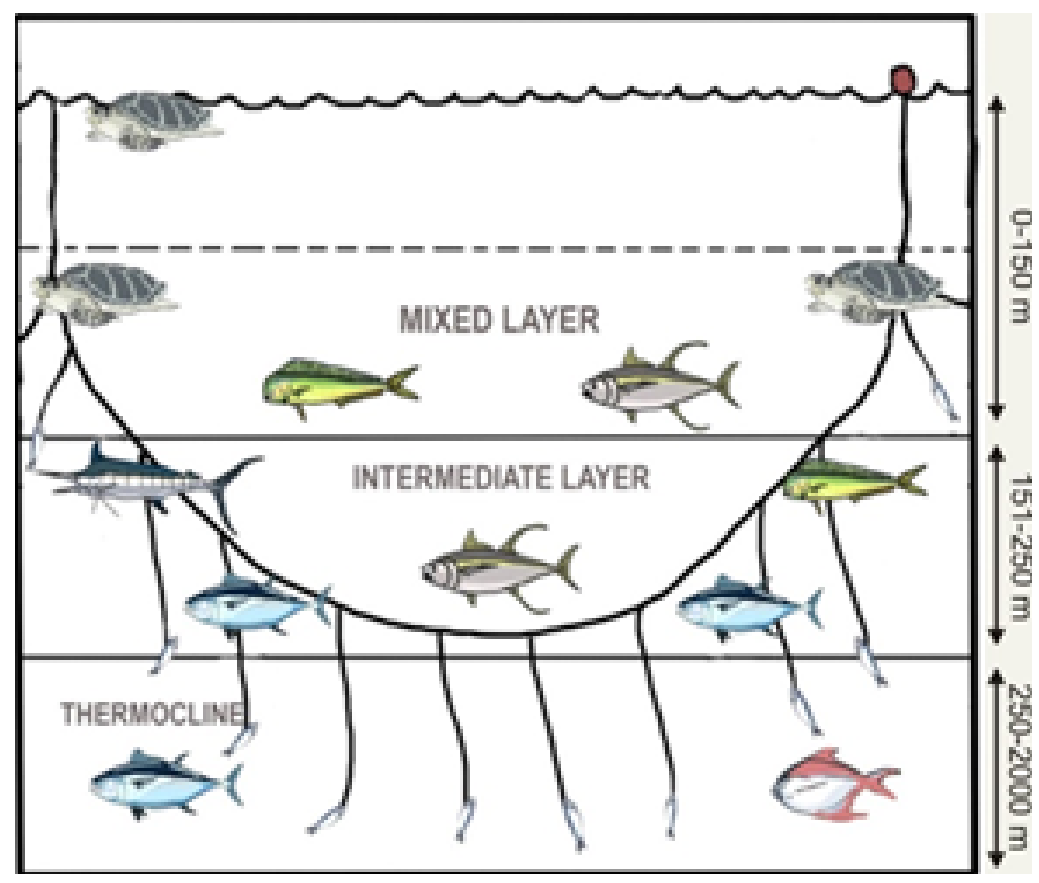

Gambar 10. Ilustrasi kaitan ikan yang tertangkap pada long line dengan rata-rata kedalaman long line

\section{METODE PENELITIAN}

Raw data penangkapan diperoleh dari logbook penangkapan Pelabuhan Perikanan Samudera Cilacap (PPS Cilacap) sepanjang tahun 2017. PPS Cilacap banyak mengcover aktivitas dari penangkapan ikan di bagian tengah perairan Selatan Jawa. Daerah kajian sebaran penangkapan pada penelitian ini berada di $6^{\circ}-14^{\circ} \mathrm{LS}$ dan $103^{0}-115^{\circ}$ BT. Logbook konsisten mencatat beberapa parameter diantaranya: jenis alat tangkap, spesies yang diperoleh, jumlah hasil tangkap, lokasi penangkapan, waktu penangkapan, panjang kapal, jumlah ABK dan lama waktu penangkapan. Parameter yang digunakan dalam penelitian ini antara lain: jenis alat tangkap, spesies yang diperoleh, jumlah hasil tangkap, lokasi penangkapan dan waktu penangkapan. Penelitian dilakuan di perairan Selatan Jawa (Gambar 11).

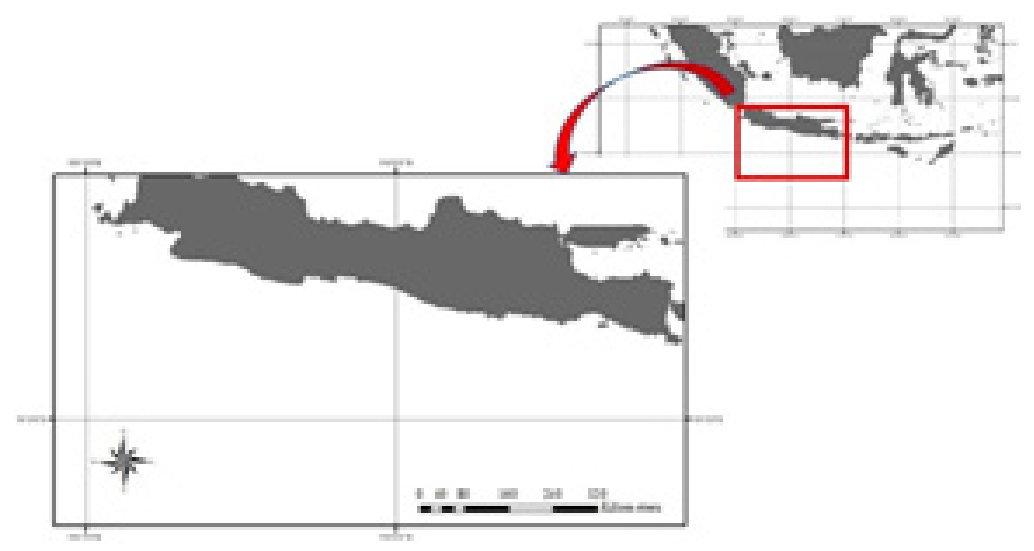

Gambar 11. Lokasi penelitian 


\section{Analisis sebaran daerah tangkapan}

Data logbook yang diperoleh diklasifikasikan berdasarkan bulan, ditinjau dari waktu tangkap. Data lokasi penangkapan berupa keterangan titik kordinat longitude dan latitude yang dipindahkan kedalam ArcGis 10.5 berupa bentuk titik pada peta spasial. Data jumlah hasil tangkap yang satuannya kg diklasifikasikan jumlahnya, antara 1-40 $\mathrm{kg}$, 41-80 kg, 81-120 kg, dan >120 kg. Besaran klasifikasi ini diekspresikan dalam ukuran besar lingkaran, semakin besar klasifikasinya semakin besar juga bentuk lingkaranya pada peta spasial. Pemberian warna berbeda diberikan kepada hasil peta spasial sebaran daerah tangkap gill net dan long line agar mudah dipahami.

\section{HASIL DAN PEMBAHASAN}

Laporan statistik perikanan tangkap PPS Cilacap tahun 2017 menyatakan armada perikanan yang berpangkalan sebanyak 646 unit, dengan komposisi berdasarkan jumlah jenis alat tangkap didominasi oleh long line sebanyak 173 unit, jaring insang monofilamen sebanyak 137 unit, jaring insang hanyut sebanyak 112 unit, jaring tiga lapis sebanyak 110 unit, arad sebanyak 38 unit, pancing ulur sebanyak 17 unit, bubu sebanyak 20 unit, payang sebanyak 12 unit, jaring sirang sebanyak 8 unit, pukat cincin sebanyak 6 unit, jala jatuh sebanyak 2 unit, pancing cumi sebanyak 8 unit, kapal pengangkut 2 unit, dan rawai tetap sebanyak 1 unit (PPS Cilacap 2017).

Data logbook perikanan PPS Cilacap menunjukkan ada tiga jenis alat tangkap atau armada kapal yang beroperasi selama 2017 untuk menangkap pelagis kecil. Data logbook hanya menyebutkan alat tangkap secara umum, tidak spesifik. Persentasenya Gill Net (GN) 79\% sebanyak 246 armada, Long line (LL) 18\% sebanyak 55 armada, dan pancing 5\% sebanyak 11 armada. Jenis alat tangkap yang terdata ini dikarenakan komoditi hasil tangkap utama perairan Selatan Jawa adalah pelagis besar seperti tuna sirip kuning, tuna mata biru, dan cakalang.

Ada tiga jenis pelagis kecil yang ditemukan selama 2017 antara lain layur (Trichiurus sp.) $26.866,2 \mathrm{~kg}$, tenggiri (Scomberomorus sp.) $671 \mathrm{~kg}$, dan tongkol (Euthynnus sp.) 331,884 kg. Tongkol menjadi spesies dominan yang ditangkap di perairan Selatan Jawa. Hal ini selaras dengan Prayoga et al. (2017) menyatakan, sumberdaya ikan tongkol adalah salah satu sumberdaya perikanan paling dominan dan bernilai ekonomis tinggi yang merupakan hasil perikanan yang menjadi target tangkapan nelayan. Ikan tongkol merupakan jenis ikan pelagis yang merupakan salah satu komoditas utama ekspor Indonesia (Mujib et al. 2013).

Selatan Jawa merupakan daerah upwelling musiman (Yoga et al. 2014), sehingga kelimpahan hasil tangkap sangat mencolok ketika terjadi upwelling dan downwelling. Upwelling adalah proses naiknya massa air laut lapisan bawah ke permukaan. Hembusan angin yang mendorong berkumpulnya air pada permukaan tertentu mengakibatkan kekosongan massa air di bagian yang lain, akibatnya air yang berasal dari bawah menggantikan kekosongan yang berada di atas. naiknya air ini membawa serta air yang suhunya lebih dingin, salinitas tinggi, dan nutrien yang kaya ke permukaan (Nontji 1993). Sementara proses dan efek downwelling kebalikan dari upwelling.

Downwelling terjadi pada pada musim barat Desember, Januari, Februari (DJF) (Yoga et al. 2014; Ratnawati et al. 2016). Hal ini mengakibatkan pasokan nutrien berkurang sehingga kelimpahan klorofil dan pelagis kecil sedikit dibandingkan bulanbulan sebelumnya (Gambar 12). Melihat lebih detail, pada Desember hasil tangkap GN dan LL sebesar 4.700 dan $16.700 \mathrm{~kg}$ (Gambar 13). Sebaran daerah penangkapan pada bulan ini menyebar menjauh dari daratan untuk GN dan LL dengan jumlah yang sedikit. Bulan Januari hasil tangkap GN sangat rendah $900 \mathrm{~kg}$ bahkan LN tidak mendapat hasil sama sekali. Sebaran daerah penangkapan GN bulan Januari hanya 2 titik. Bulan Februari hampir sama dengan GN $4.075 \mathrm{~kg}$ dan LN $400 \mathrm{~kg}$, tetapi dengan daerah penangkapan yang lebih banyak dari sebelumnya.

Musim peralihan 1 adalah pada bulan Maret, April, Mei (MAM) bulan Maret hasil tangkap GN $4.975 \mathrm{~kg}$ tak jauh beda dengan bulan sebelumnya, sedangkan LL mengalami penurunan hingga 320 kg. Pada bulan April GN mengalami penurunan di titik terendah $860 \mathrm{~kg}$, LN sedikit menanjak menjadi $1.500 \mathrm{~kg}$. Bulan Mei LL terus mengalami penurunan hingga $436 \mathrm{~kg}$, sedangkan GN mulai mengalami pertambahan yang signifikan hingga $15.725 \mathrm{~kg}$ (Gambar 13). Sebaran daerah penangkapan GN bulan Maret menjadi lebih 
sedikit dari bulan sebelumnya dan menjadi semakin parah ketika memasuki April dan mulai membaik memasuki bulan Mei yang tersentral di perairan Selatan Jawa Tengah. Tetapi untuk LL baik Maret, April, atau Mei tidak mengalami perubahan yang signifikan (Gambar 12).

Yoga et al. (2014) dan Ratnawati et al. (2016) menyatakan, upwelling Selatan Jawa terjadi pada bulan Juni, Juli, Agustus (JJA). Formasi piramida ekosistem bila terjadi upwelling produksi primer, sekunder dan pelagis kecil terdapat perbedaan waktu maksimum pertumbuhan dan disebut dengan time scales. Sebagai contoh 5 hari untuk phytoplankton, 25 hari untuk zooplankton dan 2-3 bulan untuk pelagist kecil (Hutchings 2006; Kämpf \& Chapman 2016). Hal inilah yang menjelaskan mengapa puncak perolehan hasil tangkap secara keseluruhan terjadi pada bulan Juli, Agustus, September.

Musim Timur Juni, Juli, Agustus (JJA) hasil tangkan GN mengalami peningkatan eksponensial dari bulan sebelumnya menjadi 20.102, 47.993,
$76.634 \mathrm{~kg}$. Penyebaran daerah tangkap GN juga semakin meluas pada musim Timur ini, tidak hanya di perairan Selatan Jawa Tengah saja tetapi menyebar sampai Jawa Barat. LL Juni tidak mendapatkan hasil, kemudian Juli meningkat $18.741 \mathrm{~kg}$ dan Agustus berkurang menjadi $10.254 \mathrm{~kg}$. Sehingga bulan Juli menjadi puncak hasil tangkap untuk LL. Sebaran daerah tangkap LL pada bulan Juli dan Agustus meluas ke arah barat. Tercatat bulan Agustus menjadi puncak produksi untuk GN disebabkan karena upwelling.

Musim peralihan 2 adalah pada bulan September, Oktober, November (SON) Puncak hasil tangkapan GN yang terjadi di bulan Agustus berangsur turun bertahap pada musim peralihan 2 ini. Perolehan hasil tangkap September, Oktober, November $57.035,21.847,3.670 \mathrm{~kg}$ (Gambar 13). Hasil tangkapan LL September mengalami sedikit penurunan $9.588 \mathrm{~kg}$ tetapi menguat kembali Oktober dan November 12.838, $15.091 \mathrm{~kg}$. Sebaran daerah tangkap kedua alat tangkap juga berangsur-angsur menyempit.

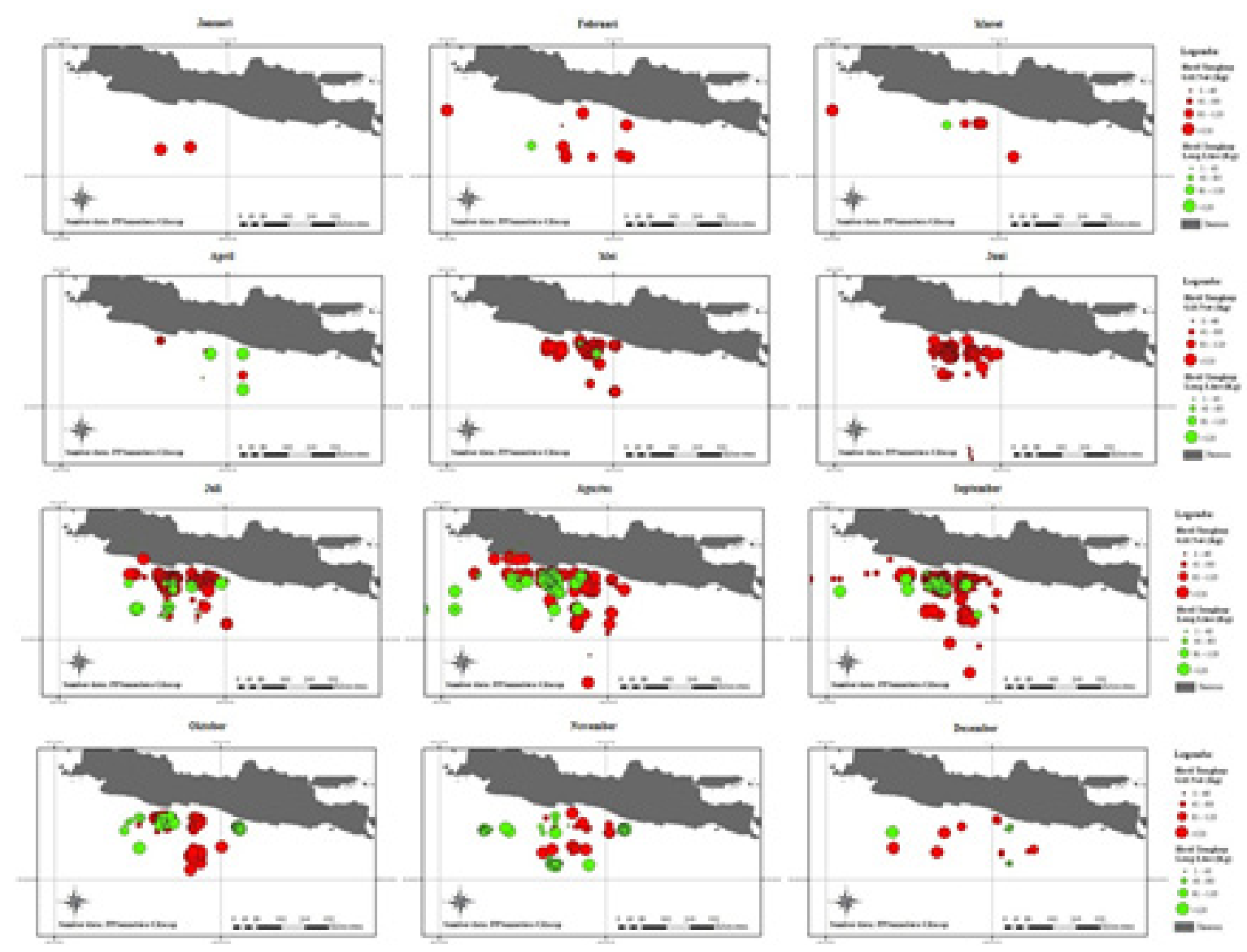

Gambar 12. Sebaran daerah tangkap ikan tongkol tahun 2017 


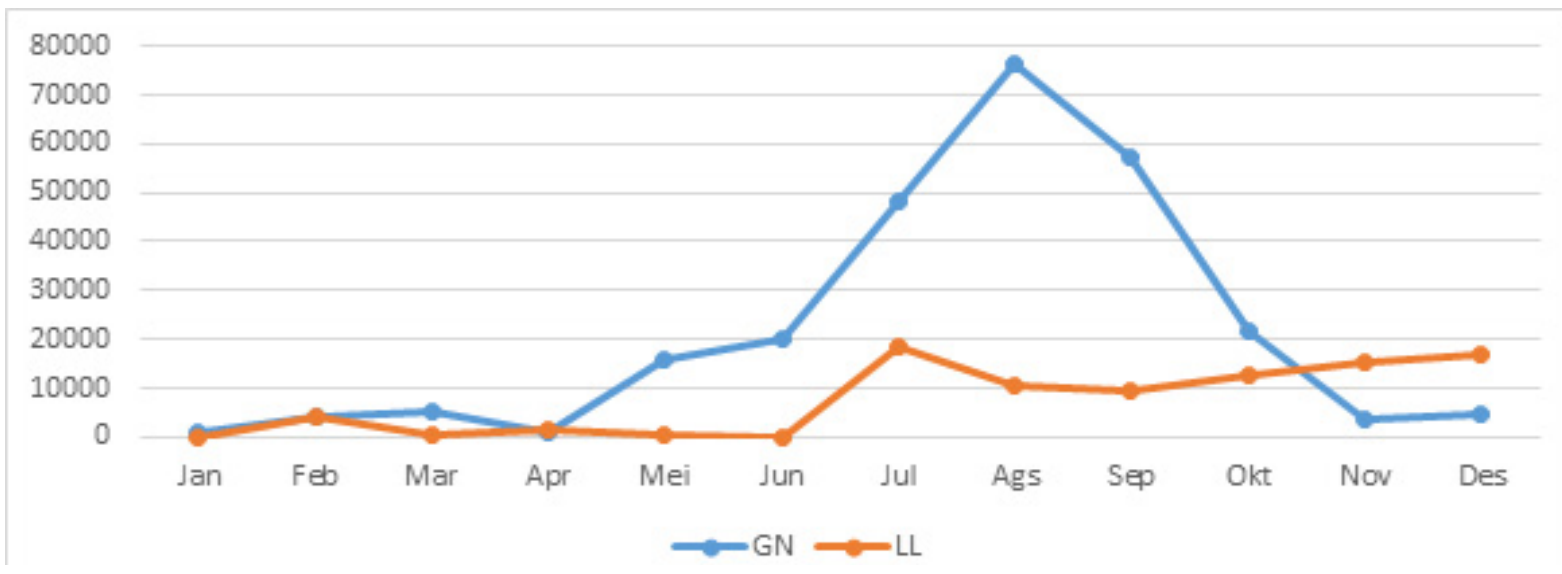

Gambar 13. Grafik perbandingan ikan tongkol $(\mathrm{kg})$ dengan alat tangkap GN dan LL

Hasil sampingan dari penelitian ini adalah ikan layur dan tenggiri yang merupakan ikan pelagis kecil yang tercatat di logbook PPS Cilacap. Hasil tangkap kedua ikan ini dibandingkan dengan ikan tongkol jauh berbeda bahkan keberadaanya tidak sepanjang tahun (Gambar 15 dan 17). Sebaran daearah tangkap kedua ikan ini bisa dilihat pada Gambar 14 dan Gambar 16.

Menarik untuk dibahas ketika nilai hasil tangkap ikan tongkol (Gambar 13) pada bulan November LL bisa melebihi GN, kemudian nilai hasil tangkap LL bulan Juli dan November menjadi hasil tangkap paling tinggi sepanjang tahun. Memecahkan hal tersebut maka penulis mengkaji sebaran menegak lapisan suhu dan salinitas perairan, mempertimbangkan suhu adalah faktor pembatas yang sangat penting di laut lepas (Laivastu \& Hela 1970). Salinitaspun juga penting karena berkaitan dengan osmoregulasi ikan. Diambilah data satelit Sea Survace Temperature (SST) dan Sea Survace Salinity (SSS) pada titik $108^{\circ}$ Bujur Timur dan 8,6 $6^{\circ}$ Lintang Selatan, yang merupakan titik relatif banyak dan sering dijumpai hasil tangkap ikan tongkol dari http://marine.copernicus.eu sehingga memperoleh hasil dapat dilihat pada Gambar 18 dan Gambar 19.

GN merupakan alat tangkap yang dioperasikan di permukaan air laut. Bila kita cermati grafik hasil tangkapnya (Gambar 13), pada bulan Juli, Agustus, September menjadi perolehan tertinggi selama 1 tahun. Dikomparasikan dengan nilai suhu permukaan (Gambar 18) pada bulan- bulan tersebut nilai rata-rata SST berkisar 26$27^{\circ} \mathrm{C}$. Hal ini mendetailkan hasil penelitian sebelumnya yang menyatakan suhu penyebaran ikan tongkol sekitar $18-29^{\circ} \mathrm{C}$
(Johnson \& Tamatamh 2013). Nilai rata-rata SSS Pada bulan-bulan tersebut berkisar 34,0-43,3\%o (Gambar 19). Hasil ini juga mendetailkan hasil penelitian sebelumnya Rizkawati (2009) menyatakan, ikan tongkol menyebar pada kisaran salinitas 32,21$34,40 \%$ o.

Salinitas permukaan dari bulan Januari-Mei berkisar 33,4-33,7 \%o yang masih tergolong kisaran toleran ikan tongkol. Posisi matahari yang berada di bagian selatan belahan bumi saat musim Barat (DJF) membuat rata-rata SST lebih panas dibandingkan musim Timur (JJA) (Fadholi 2012). Panasnya rata-rata SST Januari-Mei serta Desember (Musim Barat dan peralihan I) sekitar $28-30^{\circ} \mathrm{C}$, membuat ikan tongkol bermigrasi ke daerah yang lebih sesuai. Fenomena inilah yang menjelaskan mengapa hasil tangkap GN pada bulanbulan tersebut amat rendah dibandingkan bulan yang lain. Bulan Mei dan Juni hasil tangkap GN mulai meningkat (Gambar 13), hal ini di sebabkan rata-rata SST mulai mendekati suhu optimum $27-28^{\circ} \mathrm{C}$.

Saat terjadi upwelling bulan Juli, Agustus, September, air dingin yang terangkat dari lapisan bawah permukaan bercampur dengan lapisan permukaan, mengakibatkan penurunan suhu pada lapisan permukaan menjadi optimum 26$27^{\circ} \mathrm{C}$. Begitu juga halnya dengan salinitas yang terangkat menjadikan optimum pada permukaan 34,0-43,3\%o. Melimpahnya makanan karena upwelling juga menjadi faktor yang membuat hasil tangkap GN meningkat pesat pada bulan-bulan tersebut. Bulan Oktober, November suhu permukaan mulai beralih lagi memanas, diiringi dengan menurunya hasil tangkap GN hingga bulan Desember memasuki musim Barat kembali. 


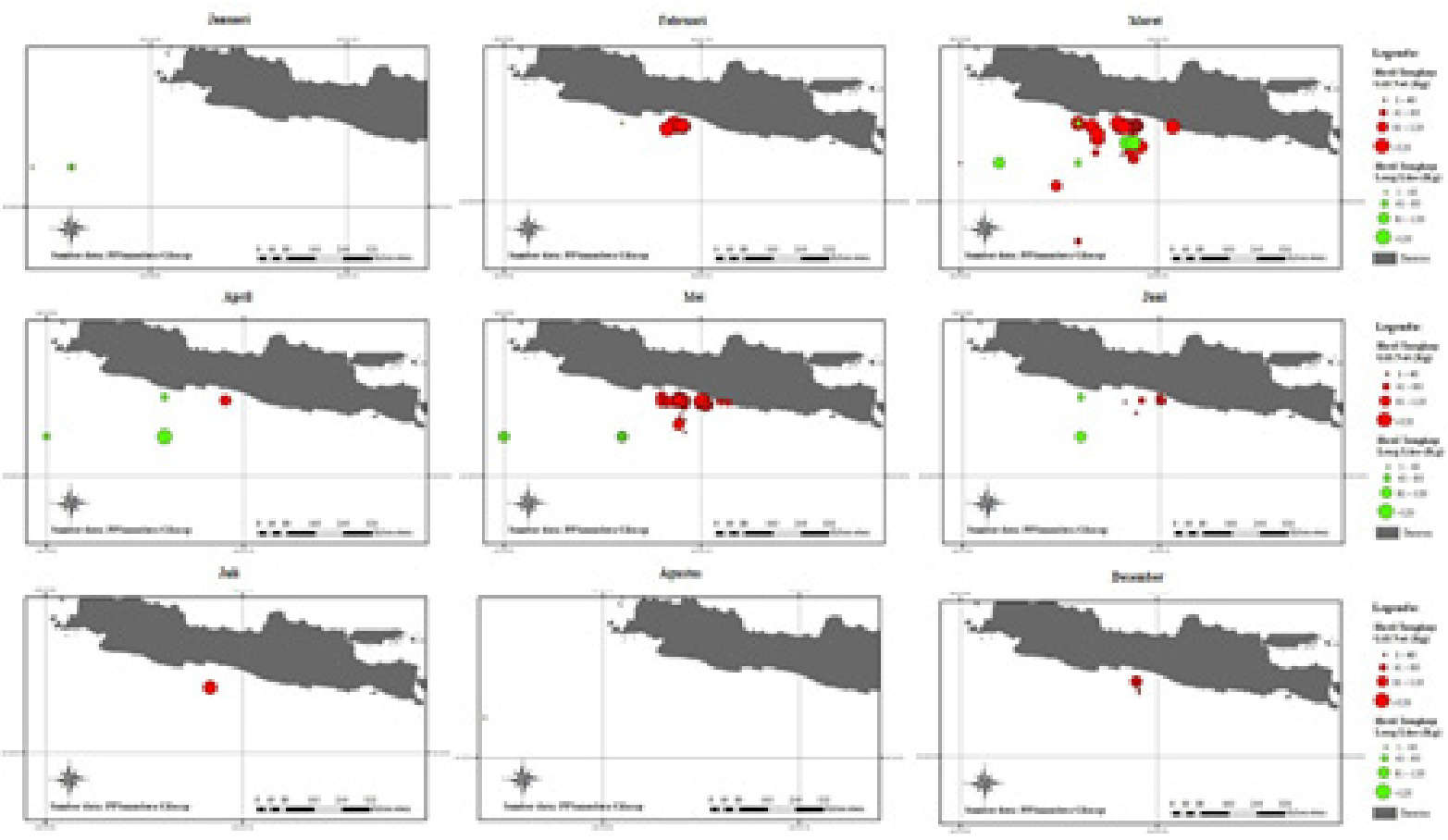

Gambar 14. Sebaran daerah tangkap ikan layur tahun 2017

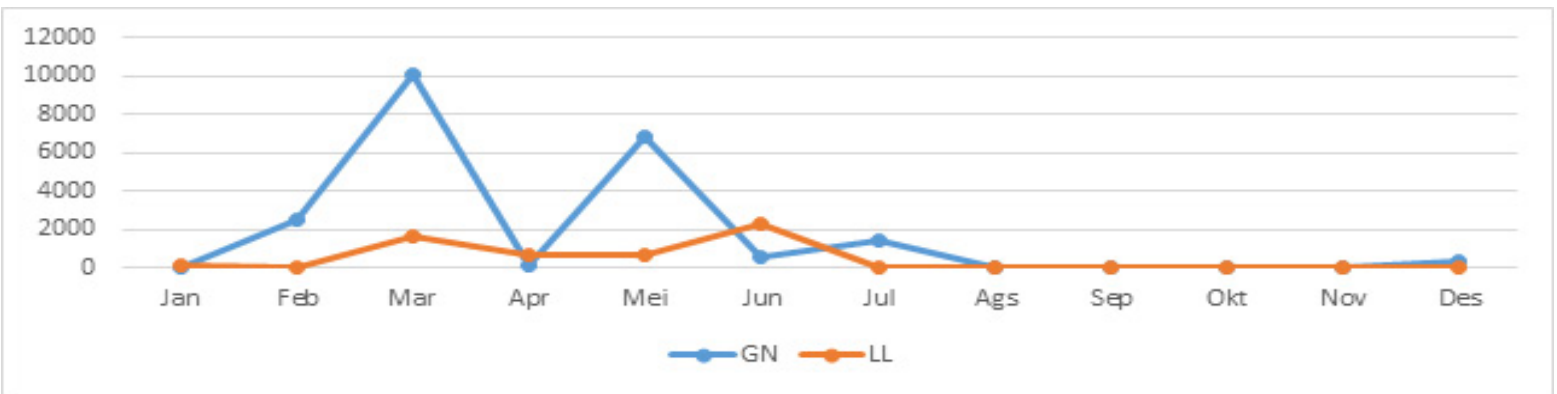

Gambar 15. Grafik perbandingan ikan layur (kg) dengan alat tangkap GN dan LL
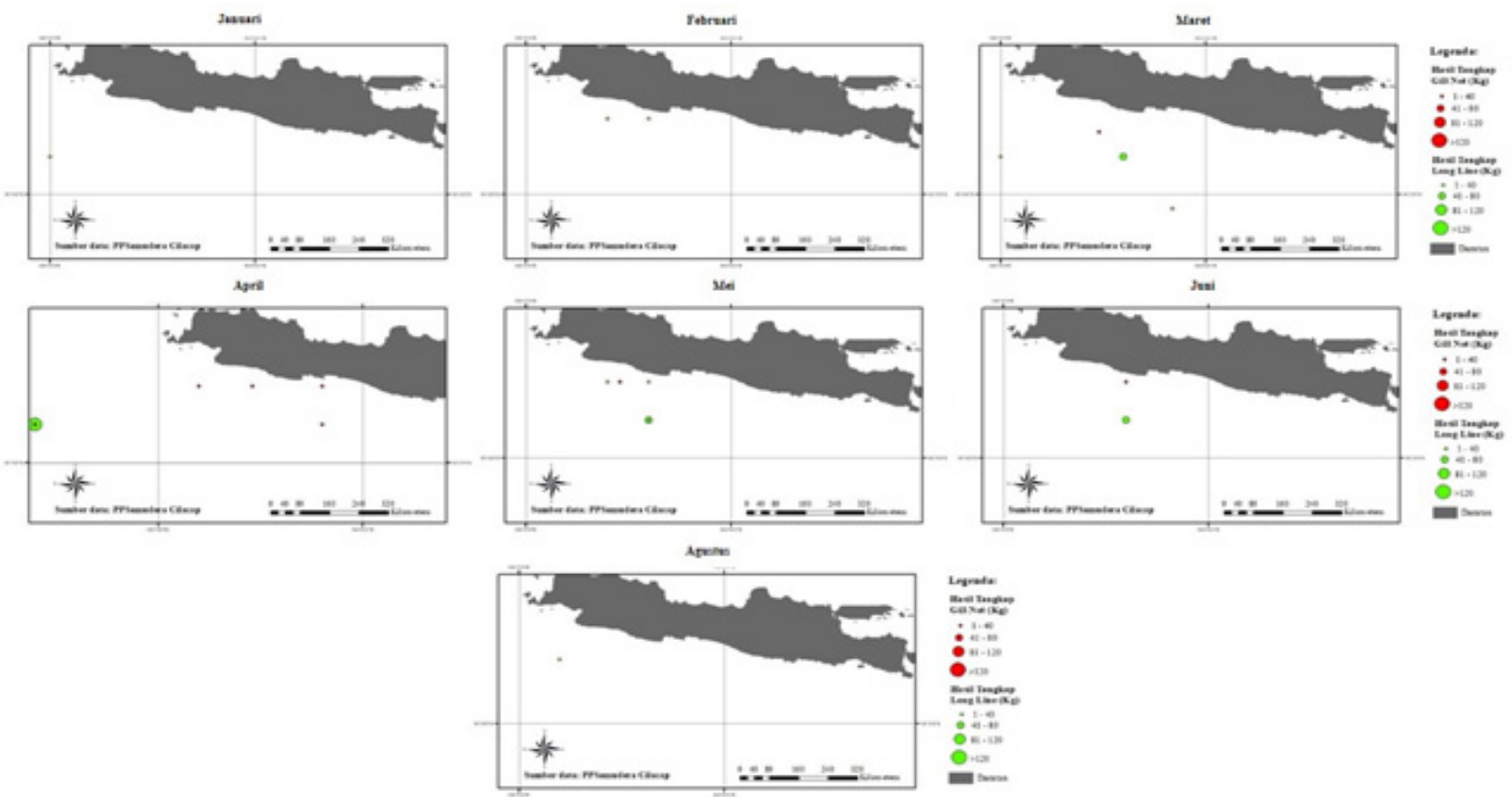

Gambar 16. Sebaran daerah tangkap ikan tenggiri tahun 2017 


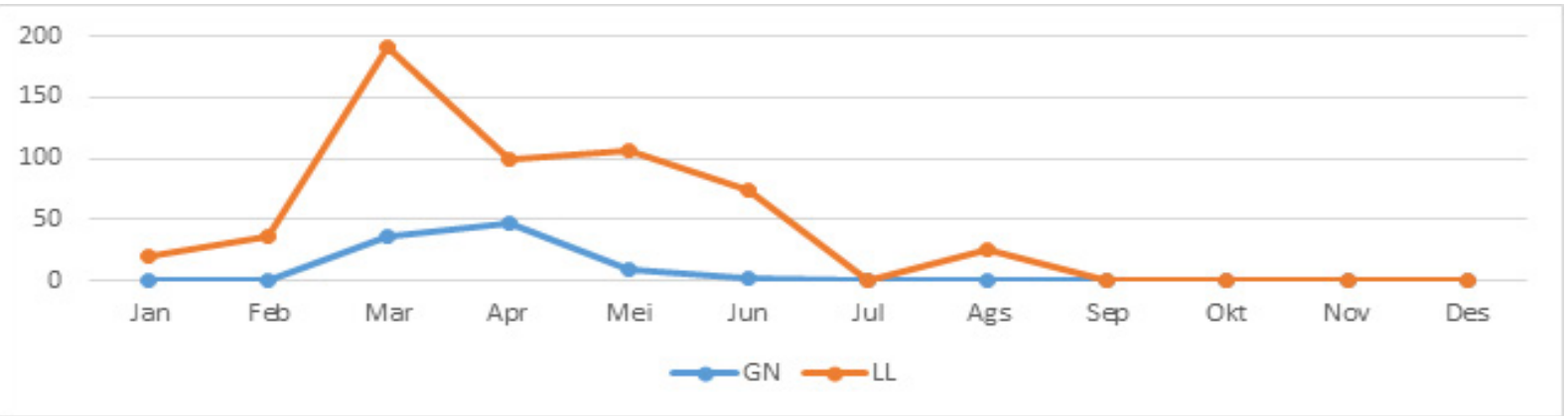

Gambar 17. Grafik perbandingan ikan tenggiri (kg) dengan alat tangkap GN dan LL

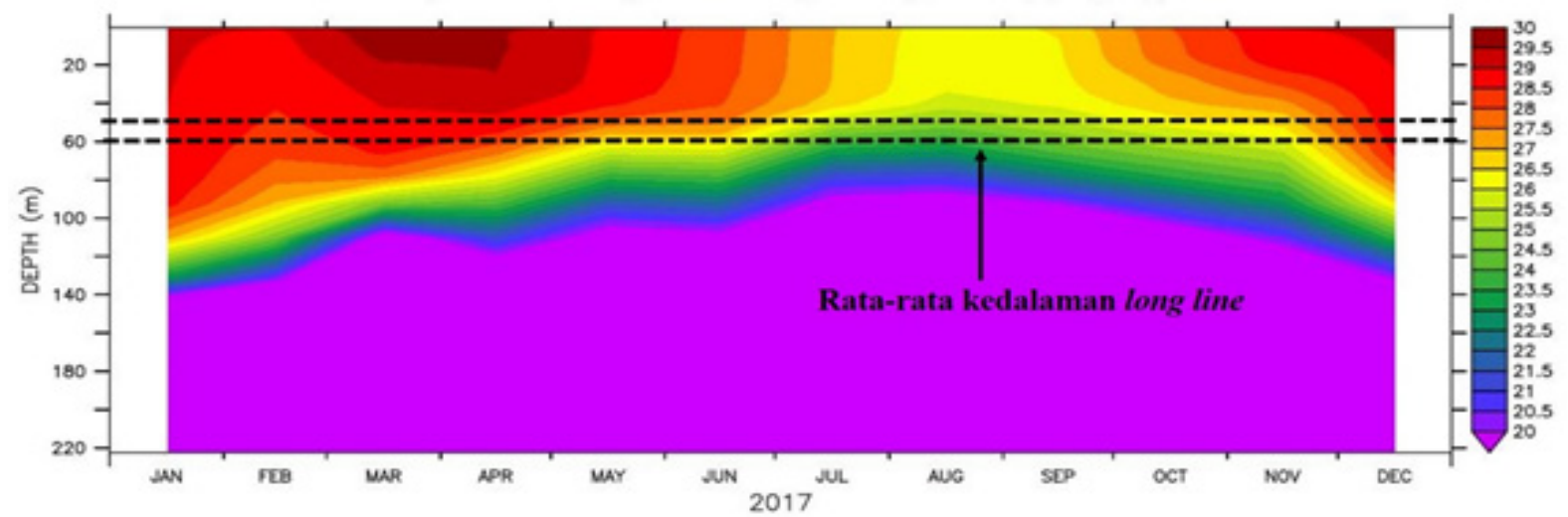

Gambar 18. Sebaran menegak lapisan rata-rata bulanan suhu perairan $\left({ }^{\circ} \mathrm{C}\right)$

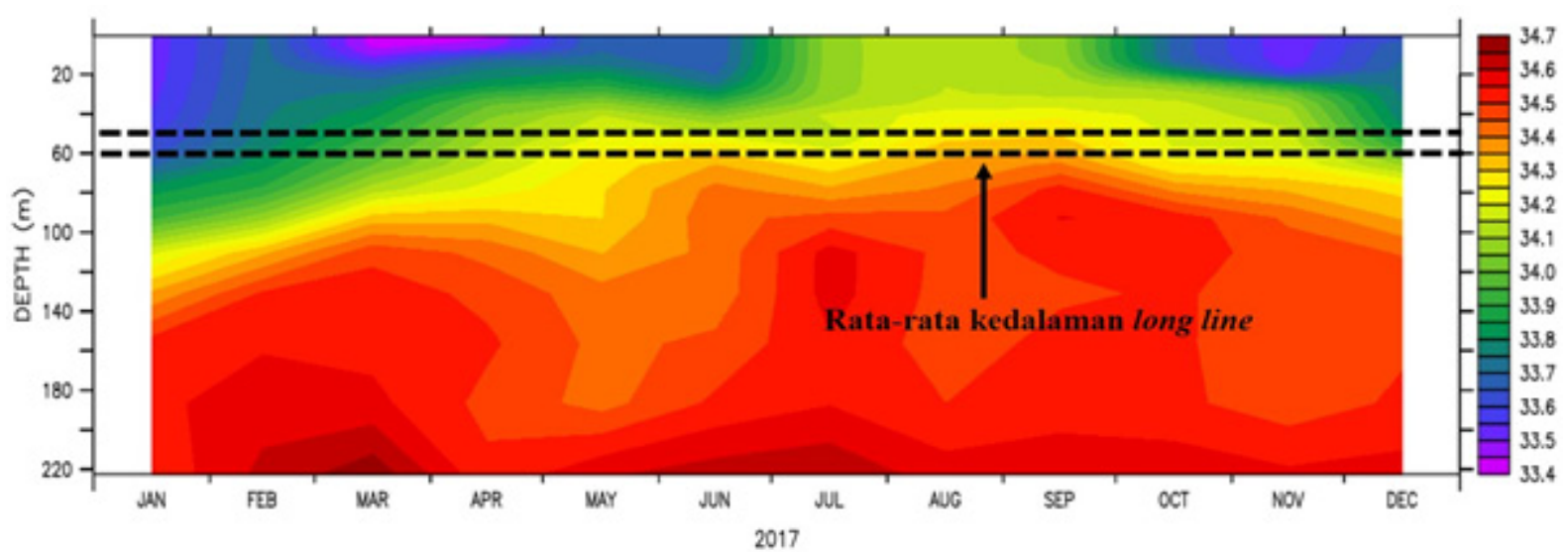

Gambar 19. Sebaran menegak lapisan rata-rata bulanan salinitas perairan (\%o)

Data PP Samudera Cilacap menunjukkan panjang kedalaman LL ratarata sekitar 51-57 m. Data ini menjadi menarik bila dihubungkan dengan kedalaman ikan berenang sesuai suhu dan salinitas optimumnya dan peluang tertangkapnya ikan oleh LL. Parameter salinitas tercatat hampir sepanjang tahun kecuali bulan Januari merupakan kisaran optimum pada kedalaman tersebut (Gambar 19). Fakta-fakta ini menyimpulkan bahwa suhu menjadi faktor pembatas utama pada lingkungan laut lepas.
Bulan Januari-Juni sebaran kedalaman suhu optimum $\left(26-27^{\circ}\right.$ C) dengan kedalaman LL bisa dikatakan tidak sinkron. Hal ini di verifikasi dengan hasil tangkap LL yang sangat rendah dari bulan Januari-Juni. Kenaikan hasil hasil tangkap bulan Juli, Agustus, September merupakan efek melimpahnya makanan karena upwelling. Walaupun sebaran kedalaman suhu optimum dan kedalaman LL juga tidak sinkron, tetapi melimpahnya makanan membuat peluang tertangkapnya ikan meningkat. Efek upwelling dan sempat 
merasakan sinkronisasi pada bulan Juli menjadi penjelasan mengapa bulan Juli menjadi merupakan puncak hasil tangkap LL tahun 2017.

Selesainya upwelling pada bulan Oktober memang menurunkan kelimpahan ikan, tetapi sebaran kedalaman suhu yang mendekati kedalaman LL (Gambar 18) membuat laju penurunan poduktivitas LL tidak terlalu besar. Puncak hasil tangkap kedua LL terjadi pada bulan November. Hal ini disebabkan karena sebaran kedalaman suhu opimum sinkron dengan kedalaman LL. Fenomena inilah yang menjelaskan, mengapa hasil tangkap LL bulan Juli dan November bisa melebihi bulan Agustus yang merupakan puncak dari upwelling. Terakhir pada bulan Desember terjadi perubahan kedalaman optimum yang sangat drastis sehingga hasil tangkap kembali menurun. Semua analisis suhu dan salinitas di atas mengimplikasikan bahwa kondisi suhu dan salinitas yang tidak sesuai ngakibatkan ikan tongkol bermigrasi sehingga bukan daerah tangkap.

\section{KESIMPULAN DAN SARAN}

\section{Kesimpulan}

Sebaran daerah penangkapan ikan tongkol (Euthynnus sp.) untuk alat tangkap gill net adalah $105,56^{\circ}-110,78^{\circ} \mathrm{BT}$ dan $7,48^{\circ}$ $11,57^{\circ} \mathrm{LS}$ serta untuk alat tangkap long line adalah $106,69^{\circ}-109,46^{\circ} \mathrm{BT}$ dan $7,84^{\circ}$ $9,37^{\circ}$ LS. Sebaran daerah penangkapan ikan tongkol menggunakan gill net tertinggi pada bulan Agustus dengan perolehan hasil tangkap $76.634 \mathrm{~kg}$, sedangkan menggunakan long line pada bulan Juli dengan perolehan hasil tangkap $18.741 \mathrm{~kg}$.

Sebaran menegak lapisan ratarata bulanan suhu perairan untuk ikan tongkol optimum pada bulan Juli, Agustus, September untuk gill net dan bulan Juli serta November untuk long line yaitu 26$27^{\circ}$ C. Sebaran menegak rata-rata bulanan salinitas perairan untuk ikan tongkol juga optimum bulan Juli, Agustus, September untuk gill net dan long line sepanjang tahun kecuali bulan Januari merupakan kisaran optimum yaitu berkisar 34,0-43,3\%o.

\section{Saran}

Penangkapan ikan tongkol di perairan Selatan Jawa optimum bulan Mei-Agustus menggunakan gill net, kemudian optimum menggunakan long line pada bulan Juli dan November.

\section{UCAPAN TERIMAKASIH}

Ucapan terimakasih diberikan kepada Pelabuhan Perikanan Samudera Cilacap yang telah menyediakan data logbook perikanan dan semua pihak yang membantu penelitian ini.

\section{DAFTAR PUSTAKA}

Adyas AH, Zainudin IM, Yusuf M. 2011. Panduan Pengelolaan Tuna Longline Ramah Lingkungan untuk Menghindari Hasil Tangkap Sampingan (Bycatch). Jakarta, Indonesia. WWF-Indonesia

Barata A, Bahtiar A, Hartaty H. 2011. Pengaruh Perbedaan Umpan dan Waktu Setting Rawai Tuna terhadap Hasil Tangkapan Tuna di Samudera Hindia. Jurnal Penelitian Perikanan Laut. 17 (2) : 133-134

Fadholi A. 2012. Analisa Pola Angin Permukaan di Bandara Udara Depati Amir Pangkalpinang Periode Januari 2000-Desember 2001. Statistika. 12(1) : 19-28.

[FAO-FIGIS] Food and Agriculture Organization - Fisheries Global Information System. 2005. A world overview of species of interest to fisheries. Chapter: Ethynnus affinis. Retrieved on 30 May 2005. www.fao. org/figis / servlet/ species?fid=3294. 2 p. FIGIS Species Fact Sheets. Species Identification and Data ProgrammeSIDP. Japan. FAO-FIGIS.

Hakim L, Nurhasanah. 2017. Analisis Produktivitas, Dominasi dan Diversitas Hasil Tangkap Gill Net (studi Kasus di Pelabuhan Perikanan Pantai Talangsari). Seminar Nasional Riset Inovatif. ISBN: 978-602-642811-0.

Hakim L, Wiyono ES, Wahju RI. 2018. Kompetisi Alat Penangkapan Ikan Sekala Kecil di Pelabuhan Perikanan Pantai Tegalsari. Marine Fisheries. 9(1) : 111-120.

Hutchings L, Verheye HM, Hugett JA, Demarcq $H$, Cloete $R$, Barlow RG, Louw D, da Silva A. 2006. Variability of plankton with reference to fish variability in the Benguela Current 
large marine ecosystem: An overview. In Benguela: Predicting a Large Marine Ecosystem. $1^{\text {nd }}$ edition. Shannon, G. Hempel, P. ManalotteRizzoli, C. Moloney, and J. Woods, editor. Amsterdam, Belanda. Elsevier. Ilhamdi H, Telussa R, Ernaningsih D. 2016. Analisis Tingkat Pemanfaatan dan Musim Penangkapan Ikan Pelagis di Perairan Prigi Jawa Timur. Jurnal Ilmiah Satya Bahari. 1(1) : 52-64.

Johnson MG, Tamatamh AR. 2013. Length Frequency Distribution, Mortality Rate and Repoductive Biology of Kawakawa (Euthynus affinis-Cantor, 1849 ) in the Coastal Waters of Tanzania. Pak.J.Bio.Sci. 16 (21) : 1270-1278.

Kämpf J, Chapman. 2016. Upwelling Systems of the World, A Scientific Journey to the Most Productive Marine Ecosystems. Switzerland, Swiss. Spinger International Publishing Switzerland. doi 10.1007/978-3-31942524-5.

Kisworo R, Saputra SW, Ghofar A. 2013. Analisa Hasil Tangkapan, Hasil tangkap dan Kelayakan Usaha Perikanan Rawai Dasar di PPI Bajomulyo I Kabupaten Pati. Journal of Manegement Aquatic Resource. 2(3) : 190-196.

[KKP] Kementerian Kelautan dan Perikanan. 2017. Buku Saku Alat Tangkap Bagi Pengolah Data. Jakarta, Indonesia. KKP.

Laivastu T,Hela I. 1970. Fisheries oceanography: New ocean environmental services. Coward and Gerrish Ltd. Inggris.

Mertha IGS, Nurhuda M, Nursullah A. 2006. Perkembangan Perikanan Tuna di Pelabuhanratu. J.lit. perikanan. 12(2) : 117-127.

Mujib Z, Boesono H, Fitri ADP. 2013. Pemetaan Sebaran Ikan Tongkol (Euthynnus sp.) dengan Data Kloropil-a Citra Modis pada Alat Tangkap Payang (Danish-seine) di Perairan Teluk Pelabuhanratu Sukabumi Jawa Barat. Journal of Resource Utilization Managemen and Technology. 2(2) : 150-160.

Nontji A. 1993. Laut Nusantara, $2^{\text {ededition. }}$ Jakarta, Indonesia. Djambatan.

Nugraha B, Triharyuni S. 2009. Pengaruh Suhu dan Kedalaman Mata Pancing Rawai Tuna (Tuna Longline) terhadap Hasil Tangkapan Tuna di Samudera
Hindia. J. Pusat Riset Perikanan Tangkap. Jakarta. 15(3) : 239-247.

Nurhayati A. 2013. Analisis Potensial Lestari Perikanan Tangkap di Kawasan Pangandaran. Jurnal Akuatika. 4(2) : 195-209.

[PPS Cilacap] Pelabuhan Perikanan Samudera Cilacap. 2017. Laporan Statistik Perikanan Tangkap Pelabuhan Perikanan Samudera Cilacap tahun 2017. Cilacap, Indonesia. KKP.

Prayitno MRE, Simbolon D, Yusfiandayani R, Wiryawan B. 2017. Hasil tangkap Alat Tangkap yang Dioperasikan di Sekitar Rumpon Laut Dalam. Marine Fisheries. 8(1) : 101-112.

Prayoga IMS, Putra IDNN, Dirgayusa IGNP. 2017. Pengaruh Sebaran Konsentrasi Klorofil-a Berdasarkan Citra Satelit terhadap Hasil Tangkapan Ikan Tongkol (Euthynnus sp) Di Perairan Selat Bali. Journal of Marine and Aquatic Sciences. 3(1) : 30-46.

Puspito G. 2009. Perubahan Sifat-sifat Fisik Mata Jaring Insang Hanyut Setelah Digunakan 5, 10, 15 dan 20 Tahun. Jurnal Peneliti Sains. 12(3D) : 12310.

Ratnawati HI, Hidayat R, Bey A, June T. 2016. Upwelling di Laut Banda dan Pesisir Selatan Jawa serta Hubungannya dengan ENSO dan IOD. Omni-Akuatika. 12(3) : 119 130.

Rizkawati R. 2009. Pengaruh Suhu Permukaan Laut terhadap Hasil Tangkapan Ikan Tenggiri di Perairan Indramayu, Jawa Barat [Skiripsi]. Bogor: Institut Pertanian Bogor.

Rusmilyansari. 2012. Inventarisasi Alat Tangkap Berdasarkan Katagori Status Penangkapan Ikan yang Bertanggungjawab di Perairan Tanah Laut. Fish Scientiae. 2(4) : 141-151

Saputra SW, Solichin A, Wijayanto D, Kurohman F. 2011. Hasil Tangkap dan Kelayakan Usaha Tuna Longliner di Kabupaten Cilacap Jawa Tengah. Jurnal Saintek Perikanan. 6(2) : 8491.

Syofyan I, Isnaniah, Siregar MR. 2015. Identifikasi dan Analisis Alat tangkap Rawai Kurau (Mini long line) di Gunakan Nelayan di Kabupaten Bengkalis. Berkala perikanan terubuk. 4(2) : 89-95.

Talib A. 2017. Tuna dan Cakalang (Suatu Tinjauan: Pengelolaan Potensi Sumberdaya di Perairan Indonesia). 
Jurnal Ilmiah agribisnis dan Perikanan UMMU-Ternate. 10(1) : 37-50.

Wiyono ES. 2010. Komposisi Diversitas dan Hasil tangkap Sumber Daya Ikan Dasar di Perairan Pantai Cirebon Jawa Barat. Jurnal Ilmu Kelauan. 15(4) : 214-220.

Widodo AA, Satria F, Sadiyah L, Riyanto J. 2011. Neritic Tuna Species Caugh Drifting Gillnet in Indian Ocean Based in Cilacap-Indonesia. Presented on the Indian Ocean Tuna CommissionWorking Party on Neritic Tuna. Chennai, 14-17 November 2011.

Yoga RB, Setyono H, Harsono G. 2014. Dinamika Upwelling dan Downwelling Berdasarkan Varibilitas Suhu Permukaan Laut dan Klorofil-a di Perairan Selatan Jawa. Jurnal Oseanografi. 3(1) : 57-66. 